\title{
Is bilateral jugular venous sampling a suitable strategy for primary hyperparathyroidism cases with parathyroid glands that cannot be localized with Sestamibi?
}

\section{Sestamibi ille lokalize edilemeyen primer hiperpara- troidilerde bilateral juguler venöz örnekleme uygun bir stratejimidir?}

Hüseyin Alakuş ${ }^{1}$, Mustafa Göksứ2, Mahmut Çoraplı ${ }^{3}$

${ }^{1}$ Department of Surgical Oncology, Adiyaman University Faculty of Medicine, Adiyaman, Turkey

${ }^{2}$ Department of General Surgery, Adiyaman University Faculty of Medicine, Adiyaman, Turkey

${ }^{3}$ Department of Radiology, Adiyaman University Training and Research Hospital, Adiyaman, Turkey

Corresponding author: Mustafa Göksu, MD, Department of General Surgery, Adıyaman University Faculty of Medicine, Adıyaman, Turkey

E-mail: drmustafagoksu@gmail.com

Received/Accepted: June 01, 2021 /November 08, 2021

Conflict of interest: There is not a conflict of interest.

\section{SUMMARY}

Objective: Primary hyperparathyroidism (PHPT) is a common disorder. The surgical excision of all hyperfunctional parathyroid tissues is required to ensure long-term eucalcemia in these patients' curative treatment. This study aimed to evaluate whether parathormone (PTH) measurement via bilateral jugular venous sampling (BJVS) is an appropriate strategy for parathyroid adenoma lateralization in PHPT cases where parathyroid glands cannot be localized by imaging.

Method: The study included 22 cases diagnosed with PHPT, which could not be localized by ultrasonography and technetium- $99 \mathrm{~m}$ sestamibi scintigraphy (99mTc-MIBI). The patients' PTH levels were measured using BJVS, and unilateral neck exploration (UNE) was performed in those detected to have lateralization. Success rate, permanent or temporary recurrent laryngeal nerve (RLN) injury, and hypoparathyroidism were evaluated.

Results: Parathyroid adenoma was successfully excised in 21 of 22 patients, and the success rate of PTH determination with BJVS was observed to be 94.5\%. RLN injury and persistent hypoparathyroidism were not observed in any patient. Transient hypoparathyroidism was present in $9 \%$ of the patients.

Conclusions: In PHPT cases where parathyroid glands cannot be localized on ultrasonography and 99mTc-MIBI, UNE can be safely performed after achieving PTH level lateralization with preoperative BJVS without the need for advanced imaging methods.

Keywords: Hyperparathyroidism, primary; parathyroid glands; parathyroidectomy; parathyroid venous sampling; preoperative localization

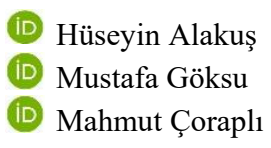

ORCID IDs of the authors: H.A. 0000-0003-2650-7208 M.G. 0000-0002-1807-6957 M.Ç. 0000-0002-4223-7845 
Amaç: Primer Hiperparatiroidizm (PHPT), endokrinolojik bozukluklar arasında sık görülen bir hastalıktır. Bu hastaların küratif tedavisinde uzun süreli ökalsemi sağlamak için hiperfonksiyonel paratiroid dokularının tamamının cerrahi olarak eksizyonu gerekmektedir. Bu çalışmanın amacı PHPT'li hastalarda görüntüleme ile lokalize edilemeyen olgularda bilateral juguler venöz örnekleme yoluyla parathormone ölçümünün, paratiroid adenom lateralizasyonu için uygun bir strateji olup olmadığını değerlendirmeyi amaçlamaktadır.

Yöntem: Ekim 2017 - Aralık 2020 tarihleri arasında PHPT tanısı konulan, Ultrasonografi ve teknesyum-99m sestamibi sintigrafi (99m Tc-MIBI) ile lokalize edilemeyen 22 hastaya preoperatif lateralizasyon için Bilateral Juguler Venöz Örnekleme (BJVS) ile PTH düzeyleri ölçülerek lateralizasyon saptanan hastalara tek taraflı boyun eksplorasyonu (UNE) yapıldı. Başarı oranı, kalıcı veya geçici rekürren sinir (RLN) hasarı ve hipoparatiroidizm değerlendirildi.

Bulgular: 22 hastanın 21 'inde paratiroid adenomu başarılı bir şekilde eksize edildi ve BJVS ile PTH tayinin başarısı \%94.5 olduğu gözlendi. RLN hasarı ve kalıcı hipoparatiroidizm hiçbir hastada gözlenmedi. Hastaların \%9'unda geçici hipoparatiroidizm izlendi.

Sonuç: US ve 99m Tc-MIBI ile lokalize edilemeyen PHPT'li hastalarda ileri görüntüleme yöntemlerine gerek kalmadan Bilateral Boyun Diseksiyonu'ndan (BNE) kaçınmak için preoperatif BJVS ile PTH düzeyi lateralizasyon sağlanan hastalarda UNE güvenle yapılabilir.

Anahtar sözcükler: Primer hiperparatiroidizm; paratiroid bezi; paratiroidektomi; paratiroid venöz örnekleme; preoperatif lokalizasyon.

\section{INTRODUCTION}

Primary hyperparathyroidism (PHPT) ranks third among endocrinological disorders, seen in 1 out of 700 patients and affecting $3 \%$ of postmenopausal women and $4 \%$ of men ${ }^{1}$. PHPT is an endocrine disorder that causes high serum calcium and low serum phosphorus levels due to increased parathyroid hormone (PTH) production by the parathyroid glands ${ }^{2}$. PHPT is caused by a solitary adenoma in $80-85 \%$ of patients ${ }^{3}$.

The most effective treatment for PHPT is the surgical removal of the parathyroid gland or glands that produce excessive parathormone $(\mathrm{PTH})^{1}$. In patients with PHPT, although the standard surgical approach is bilateral neck exploration (BNE), minimal invasive parathyroidectomy (MIP) is the preferred surgical procedure for cases that can be localized by imaging studies ${ }^{4}$. Compared to traditional BNE, MIP can lead to surgical complications such as smaller incision, less dissection area, less postoperative pain, less scar tissue, and lower incidence of hypocalcemia ${ }^{5}$. BNE increases both the operative time and the complication rate ${ }^{6,7}$. The accurate preoperative determination of parathyroid gland localization is very important for surgical planning in patients with PHPT. Various localization techniques are used to identify patients with PHPT to be treated with a minimally invasive surgical technique. In addition, localization studies should be performed in patients with recurrent disease or a history of neck surgery. The success of the minimally invasive method applied depends on accurate imaging results that provide guidance in limiting surgical dissection to the area where the adenoma is located. Localization studies help minimize the extent of the surgery to be performed and identify the pathological parathyroid tissue. They also assist in identifying possible coexisting thyroid pathologies. Thus, they contribute to the success of the surgical procedure by reducing perioperative complications such as recurrent laryngeal nerve (RLN) injury, permanent hypoparathyroidism and persistent disease and operation time. Therefore, various pre-operative imaging methods are used in patients with PHPT ${ }^{8}$. The most commonly used imaging method for primary surgery is the use of ultrasonography (US) and technetium-99m sestamibi scintigraphy (99mTc-MIBI) together, with the sensitivity of this combination reaching $80-90 \%^{9-11}$.

Additional complementary techniques are required for patients with PHPT with suspicious or undetectable results obtained from US and 99mTcMIBI. The most common imaging modalities providing successful results include fourdimensional computed tomography (4D-CT), magnetic resonance imaging (MRI), SPECT combined with CT (SPECT-CT), and 11Cmethionine positron emission tomography combined with 4D-CT (PET/CT). 4D-CT and MRI provide more sensitivity (88\%) in the localization of diseased parathyroid glands than US and 99mTc-MIBI ${ }^{12}$. 4D-CT and MRI are used as secondary or confirmatory imaging modalities in many centers ${ }^{13}$. SPECT-CT and PET-CT have also started to take their place as one of the imaging methods that can be considered for imaging the parathyroid gland before invasive procedures. However, pathological glands cannot be localized by non-invasive methods in approximately $10-20 \%$ of patients with PHPT (10). In these patients, invasive methods such as selective parathyroid venous sampling (SPVS), central jugular venous sampling (CJVS), bilateral jugular venous sampling (BJVS), parathyroid arteriography, fine- 
needle aspiration biopsy, and parathormone measurements are utilized ${ }^{13}$. SPVS has been proposed as a useful invasive procedure in cases that cannot be localized by preoperative imaging methods 14, ${ }^{15}$. However, many studies have reported contradictory results about the efficacy of SPVS ${ }^{16,17}$. In the literature, localization studies, albeit small in number, have been undertaken by performing CJVS and comparing the PTH levels taken from the central jugular vein with the peripheral PTH levels ${ }^{18-20}$.

In this study, we aimed to examine the efficacy of unilateral neck exploration (UNE) with the BJVS method in PHPT cases in which parathyroid glands could not be localized on US and 99mTc-MIBI.

\section{MATERIAL AND METHODS}

This study was carried out after obtaining approval from the Clinical Research Ethics Committee of Adiyaman University (protocol number: 2020/610, dated 23.06.2020).

Patient selection: The files of the patients who underwent surgery for parathyroid adenomas between July 2017 and July 2020 at the General Surgery Clinic of Adiyaman University Training and Research Hospital were retrospectively reviewed in detail. Of these patients, 22 with preoperative US and PHPT that could not be localized with 99mTc-MIBI, who underwent parathyroidectomy with UNE after achieving with BJVS were included in the study. Patient age, gender, biochemical test results, final pathology results, early and postoperative complications, and the success rate of the procedure were recorded.

Parathyroidectomy indication: Based on the decision of a multidisciplinary council, parathyroidectomy was recommended for patients with a serum calcium level of higher than the upper limit of the normal range $(>1 \mathrm{mg} / \mathrm{dl})$, those with decreased bone mineral density (a significant decrease in bone mineral densitometer in the lumbar vertebrae, hip bones or distal radius, a peak bone mass below 2.5 SD, and $\mathrm{T}$ score $<-2.5$ ), those with renal failure (glomerular filtration rate $<60$ $\mathrm{ml} / \mathrm{min}$ ) or nephrolithiasis, and those younger than
50 years of age, who did not want to or could not undergo long-term medical treatment.

The study included PHPT cases with a high PTH level and symptomatic or asymptomatic hypercalcemia, in which localization was not possible by imaging methods but lateralization was achieved with BJVS. Patients for whom imaging methods were able to localize pathological glands were not included in the study.

Lateralization: USA procedures were applied to the patients using a Toshiba Aplio 300 (Toshiba Medical System, Tokyo, Japan) ultrasonography device and an 11-Mhz linear array transducer. After local cleaning, aspiration was performed by back maneuvering into the distal of both internal jugular veins with $21 \mathrm{G}$ green-tipped $10 \mathrm{cc}$ injectors under ultrasonography. Venous sampling was performed from the bilateral jugular vein immediately before its junction with the subclavian vein. A $5 \mathrm{cc}$ of venous blood sample was placed in separate biochemistry tubes by indicating the side (right or left). PTH levels were simultaneously measured by taking venous blood samples from the antecubital region of the forearm. A difference of $5 \%$ in BJVS was found sufficient for lateralization.

Surgical technique: It is very important to obtain the best surgical results with an experienced surgical team using the technique appropriately with the knowledge of parathyroid anatomy and embryology. The patient is placed on the operating table in a supine position. UNE is performed under general anesthesia. After general anesthesia, the neck is brought into hyperextension. A $2-4 \mathrm{~cm}$ transverse incision is made $2 \mathrm{~cm}$ above the jugular notch. Upper and lower flap dissections are performed. The strap muscles are separated from the midline. First, the inferior parathyroid gland is explored. If it is morphologically pathological, parathyroidectomy is performed, and if not, it is left in place. Then, the same procedure is performed within the superior parathyroid gland. If there is additional thyroid pathology, standard thyroidectomy is performed. After bleeding control, the incision is closed primarily in the anatomical plane, and the operation is terminated (Figure $1 \mathrm{~A}-\mathrm{F}$ ). 


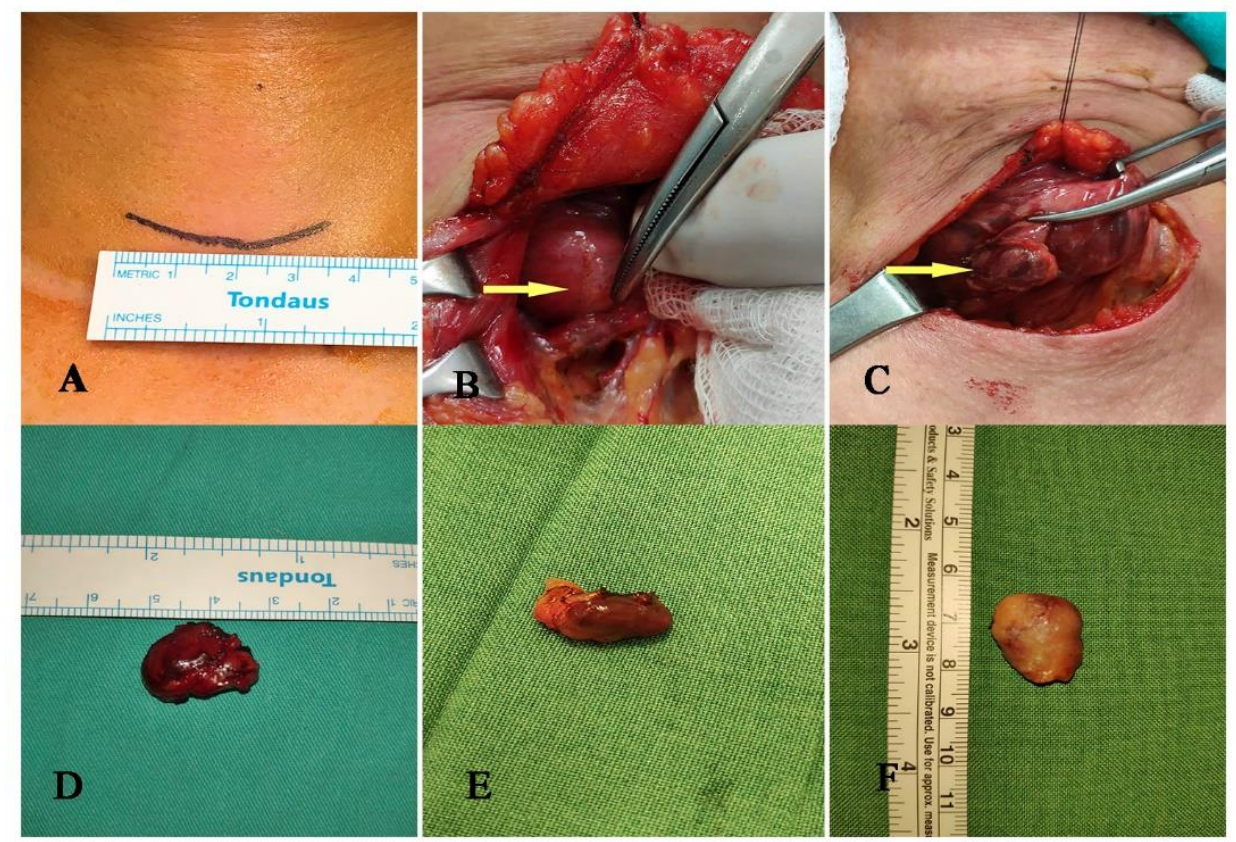

Figure 1: A. Image of skin incision

B-C. Perioperative images of parathyroid adenomas

D-F: Postoperative images of excised parathyroid adenomas

Postoperative follow-up: The calcium and PTH levels of the patients were examined at the postoperative second week and sixth month, and annually thereafter. Persistent hyperparathyroidism was accepted as hypercalcemia that persisted for at least six months following parathyroidectomy, and recurrent hyperparathyroidism was defined as developing hypercalcemia after six months or longer. Permanent hypocalcemia was evaluated based on a total serum calcium level of less than $8 \mathrm{mg} / \mathrm{dl}$ or dependence on oral calcium carbonate or calcitriol supplementation to prevent symptoms of hypocalcemia.

Statistical analysis: Statistical analysis was performed using the Statistical Package for the Social Sciences (version 25.0, SPSS, Chicago, IL, USA). Numerical variables were expressed as mean and standard deviation of minimum and maximum values, while categorical variables were expressed as numbers and percentages. One-way analysis of variance (ANOVA) was used for nonparametric values, and for comparisons. A $p$ value of $<0.05$ was accepted as statistically significant.

\section{RESULTS}

The records of 22 patients who underwent surgery for PHPT at the General Surgery Clinic of Adiyaman University Training and Research
Hospital between October 2017 and December 2020 were retrospectively reviewed. There were 18 (81.8\%) women and 4 (18.2\%) men. The mean age was 55.82 years ( $\min 25$ years, $\max 76$ years). The mean follow-up time was 20.92 months (1-39 months).

In patients detected to have lateralization with BJVS, the mean ipsilateral jugular vein PTH level was $727.66 \mathrm{pg} / \mathrm{dl}$ (90.80-3342.00), the mean contralateral jugular vein PTH level was 235.89 $\mathrm{pg} / \mathrm{dl}$ (61.40-843.10), and the mean peripheral PTH level was $237.15 \mathrm{pg} / \mathrm{dl}$ (82.60-843.00). The difference in the PTH level between the ipsilateral and contralateral jugular veins was $491.77 \mathrm{pg} / \mathrm{dl}$ (16.20-2816.00). Lateralization was detected in the right jugular vein in 12 patients and in the left jugular vein in 10 patients.

The mean preoperative calcium value of the patients was $11.6 \pm 0.71 \mathrm{mg} / \mathrm{dl}(\mathrm{min} 10.3-\mathrm{max} 13.2$ $\mathrm{mg} / \mathrm{dl}$ ), and their mean postoperative calcium value were $9.1 \pm 0.60 \mathrm{mg} / \mathrm{dl}(\min 8.1-\mathrm{max} 10.3 \mathrm{mg} / \mathrm{dl})$.

Parathyroid adenomas were detected in 21 of 22 patients with UNE. Parathyroid adenoma excision was performed in the right inferior location in nine (40.9\%) patients, right superior in two $(9.1 \%)$, left inferior in seven $(31.8 \%)$, and left superior in three (13.1\%) (Table 1). 
Table 1: Mean ipsilateral jugular PTH values and parathyroid adenoma localization $\mathrm{PTH}$, parathormone

\begin{tabular}{|c|c|c|}
\hline Jugular PTH $(\mathbf{p g} / \mathbf{m l})$ & Success $(\mathbf{n}=\mathbf{2 1})$ & Failure $(\mathbf{n}=\mathbf{1})$ \\
\hline Minimum jugular PTH ratio/difference & $0.07 / 23.20$ & $0.08 / 16.20$ \\
\hline $\begin{array}{c}\text { Maximum jugular PTH ratio/fark } \\
\text { difference }\end{array}$ & $9.65 / 2816.00$ & $0.08 / 16.20$ \\
\hline
\end{tabular}

PTH, parathormone

Imaging studies were performed with US and 99mTc-MIBI in all patients. While nine (40.9\%) patients were suspected to have a parathyroid adenoma by US, only two (9\%) patients had suspected weak involvement according to $99 \mathrm{mTc}-$
MIBI, and the US and $99 \mathrm{mTc}-\mathrm{MIBI}$ imaging studies of the remaining patients were not successful. We evaluated the success rates of the imaging methods and BJVS (Table 2) and determined that the latter had a higher success.

Table 2: Success rates of methods used to determine adenoma laterality

\begin{tabular}{|l|r|r|r|}
\hline \multicolumn{2}{|c|}{ Variables } & \multicolumn{1}{|c|}{ Right } & \multicolumn{2}{|c|}{ Left } \\
\hline \multicolumn{2}{|c|}{ Mean ipsilateral jugular PTH (pg/ml) } & 909.81 & 578.35 \\
\hline Parathyroid localization & Superior & 2 & 7 \\
\cline { 2 - 5 } & Inferior & 9 & 10 \\
\hline Total (n = 21) & & 11 & 3 \\
\hline
\end{tabular}

Table 3: Ratios and differences (percentage and absolute values) of jugular PTH levels according to success or failure in determining parathyroid adenoma laterality

\begin{tabular}{|c|c|c|c|}
\hline Method & n & Success \% & P value \\
\hline Jugular vein sampling & 21 & 95.4 & $<0.01$ \\
\hline 99m Tc-MIBI & 2 & 9.0 & 0.909 \\
\hline Ultrasound & 9 & 40.9 & 0.591 \\
\hline
\end{tabular}


In patients with a parathyroid adenoma, while the difference in the ipsilateral minimum jugular vein PTH level was $23.20 \mathrm{pg} / \mathrm{dl}(0.07)$, the difference in the maximum jugular vein PTH level was 2816.00 $\mathrm{pg} / \mathrm{dl}$ (9.65). For the single case in which the procedure failed, the ipsilateral jugular vein PTH level was found to be $16.20 \mathrm{pg} / \mathrm{dl}$ (0.08). In this patient, resampling was postoperatively performed, and since lateralization continued in the right jugular vein, the possibility of an ectopic parathyroid adenoma was considered (Table 1).

Of all the patients, $68.2 \%$ had accompanying thyroid pathologies and underwent simultaneous thyroidectomy. The final pathology of the two of these patients was reported as thyroid papillary carcinoma.

In the postoperative period, transient hypocalcemia developed in $9 \%$ of the patients who were then followed up with oral calcium and calcitriol treatment. Recurrent nerve paralysis and persistent hypocalcemia were not observed in any patient. Persistent hypercalcemia was observed in one male patient. In the jugular vein sampling performed on this patient, lateralization continued on the same side, and he was referred to another center in order for advanced imaging methods to be applied for localization.

\section{DISCUSSION}

Parathyroid glands drain into the internal jugular vein through the superior, middle and inferior thyroid veins. Therefore, the PTH levels measured from the internal jugular vein are found to be higher than the systemic vein PTH levels in the presence of excessive hormone production due to parathyroid gland disease. This information has been increasingly used today to confirm the lateralization of adenoma for MIP in patients with PHPT that can be localized on US and $99 \mathrm{mTc}-$ MIBI before surgery. However, contradictory results have also been reported in the literature ${ }^{8,21}$. Furthermore, we did not find any study involving the jugular venous PTH determination and surgical results of patients with PHPT that could not be localized before primary surgery. Thus, in the current retrospective cohort study, we aimed to preoperatively determine the lateralization of the difference in the PTH level with BJVS and evaluate the results of UNE in PHPT cases where parathyroid glands cannot be localized using US and $99 \mathrm{mTc}-\mathrm{MIBI}$.

A parathyroid adenoma typically has marginal vascularity and shows an asymmetric increase in blood supply compared to adjacent thyroid tissue. While lymph nodes usually show hilar blood supply, parathyroid adenomas have a blood supply pattern originating from a polar artery ${ }^{22}$. In some studies, the sensitivity of conventional US for the localization of parathyroid pathologies is reported as $49-89 \%$, and its specificity varies between 78 and $98 \%{ }^{23-26}$. On the other hand, many disadvantages have been reported related to this procedure, including operator-related efficacy, inability to evaluate mediastinal and retroclavicular parathyroids, decreased sensitivity in multiglandular disease, and difficulties in the evaluation of intrathyroidal lesions, obese patients, differential diagnosis of lymph nodes and diagnosis of small-sized parathyroid adenomas ${ }^{27-31}$. In a meta-analysis, the sensitivity and specificity of US in parathyroid pathologies were reported to be $76.1 \%$ and $93.2 \%$, respectively ${ }^{26}$. In our study, we detected $40.9 \%$ sensitivity for US in detecting parathyroid adenomas, which is much lower than reported in the literature. We consider this to be the result of our study group consisting of patients with negative first-line imaging in PHPT. In addition, the sensitivity of US is decreased in patients with nodular or multinodular goiter, and in our study, thyroidectomy was performed in $68.2 \%$ of the patients due to goiter pathologies, which may have further reduced the sensitivity of US.

Parathyroid scintigraphy was first used by Young et al. in 1983 as tallium-Tc99m subtraction scintigraphy ${ }^{32}$. In 1989, Coakley et al. used Tc99m-99mTc-MIBI scintigraphy based on lipophilic 99mTc-MIBI that accumulated in the mitochondria-rich oxyphilic cells of parathyroid glands ${ }^{33}$. The $99 \mathrm{mTc}-\mathrm{MIBI}$ wash-out of parathyroid adenomas is slower than that of normal thyroid and parathyroid tissue in $60-85 \%$ of cases ${ }^{34}$. Scintigraphy has advantages over US because it is not operator-dependent and it can detect ectopic or deeply located posterior lesions ${ }^{10}$. In a previous study, the sensitivity of $99 \mathrm{mT}$-MIBI scintigraphy in solitary adenomas was $88.4 \%$, while it decreased to $44.5 \%$ in multiglandular hyperplasia and further down to $30 \%$ in double adenomas ${ }^{29}$. It has been reported that the sensitivity of $99 \mathrm{mTc}-\mathrm{MIBI}$ is low in the presence of thyroid nodules and cervical lymph nodes ${ }^{35}$. In our study, the sensitivity of 99mTc-MIBI scintigraphy was determined as $9 \%$. We consider that the reason for this lower value was the study group consisting of $99 \mathrm{mTc}-\mathrm{MIBI}-$ negative patients due to PHPT and $68.2 \%$ of the cases being accompanied by thyroid pathologies.

The PTH measurement method with BJVS is one of the invasive localization methods. The test is considered positive if the ipsilateral PTH value is higher than the contralateral PTH value by determining a cut-off value ${ }^{1,36,37}$. In the current 
study, we accepted a 5\% difference for lateralization to indicate a positive test result. This is generally recommended for patients with negative $99 \mathrm{mTc}-\mathrm{MIBI}$ scintigraphy after the failure of primary surgery. Ito et al., evaluating patients with negative $99 \mathrm{mTc}-\mathrm{MIBI}$ scintigraphy, achieved the localization of the abnormal parathyroid gland in $57.8 \%$ of the cases using a rapid PTH test with BJVS during parathyroid surgery (37). Ribeiro et al. performed PTH determination in 29 patients with PHPT using 99mTc-MIBI, US and BJVS, and detected lateralization in 22 patients in the venous sampling group and noted the sensitivity of this method as $75.86 \%{ }^{1}$. Ibraheem et al. argued that when localization imaging methods were negative, bilateral jugular PTH sampling was very sensitive $(74 \%)$ in the preoperative localization of parathyroid adenomas, but it should only be used to guide surgical planning in patients with recurrent or persistent $\mathrm{PHPT}^{8}$. Barczynski et al. reported that the BJVS of PTH was a simple, safe and effective method and should be used as a complementary tool for adenoma localization in cases with negative 99mTc-MIBI scintigraphy and those with multiglandular diseases ${ }^{15}$. Maceri et al. observed a significant difference between the PTH levels between the ipsilateral internal jugular vein and contralateral jugular vein, and noted that a greater difference between these values had higher accuracy in showing the laterality of adenomas ${ }^{21}$. In the current study, parathyroid adenomas were successfully excised with UNE in $21(95.4 \%)$ of the 22 patients after lateralization with BJVS.

In patients with PHPT, when parathyroid adenomas cannot be localized with imaging methods, bilateral neck exploration is performed in surgery to locate and remove abnormal gland or glands. This leads to certain complications such as RNL injury and hypoparathyroidism. Lee et al. performed bilateral neck exploration in 214 patients with parathyroid pathologies and reported that RNL injury developed in $0.9 \%$ and permanent hypoparathyroidism in $1.9 \%{ }^{7}$. In a recent study, Khokar et al. observed permanent disease in $2 \%$ of the patients operated for PHPT, recurrent disease in $<1 \%$, reoperation in $2 \%$, temporary hypoparathyroidism in $9 \%$, and temporary RNL injury in 15 patients ${ }^{6}$. In our study, none of the patients had temporary and permanent RNL injury or permanent hypoparathyroidism due to UNE. Transient hypoparathyroidism was observed in $9 \%$ of the patients.

The limitations of this study include its retrospective nature, absence of a control group for a comparative analysis, and moderate sample size.
Therefore, there is a need for prospective, controlled studies with a large number of patients to investigate correlations.

In conclusion, patients with PHPT often have a single parathyroid adenoma. Therefore, choosing the right surgical approach for the treatment of parathyroid adenomas that cannot be localized by preoperative imaging is very difficult for surgeons since this choice affects postoperative complications and operation time and costs. Thus, additional localization studies should be performed in cases where successful results cannot be obtained by first-line imaging. In centers where there is not sufficient equipment for secondary and advanced imaging studies, the BJVS method can be used to achieve lateralization. Thus, these patients can safely undergo parathyroidectomy with UNE without the need for BNE.

\section{REFERENCES}

1. Ribeiro DK, Lera MM, Fonseca ABR, das Neves MC. Analysis of PTH serum concentration from internal jugular veins of patients with primary hyperparathyroidism. Archives of Head and Neck Surgery. 2020;48(2):0-.

2. Bilezikian JP, Bandeira L, Khan A, Cusano NE. Hyperparathyroidism. The Lancet. 2018;391(10116):168-78.

3. Rao DS, Honasoge M, Divine GW, Phillips ER, Lee MW, Ansari MR, et al. Effect of vitamin D nutrition on parathyroid adenoma weight: pathogenetic and clinical implications. The Journal of Clinical Endocrinology \& Metabolism. 2000;85(3):1054-8.

4. Campbell MJ. The definitive management of primary hyperparathyroidism: who needs an operation? Jama. 2017;317(11):1167-8.

5. Urkan M, Peker Y, Ozturk E. Minimally Invasive parathyroidectomy for primary hyperparathyroidism. . Acta Endocrinologica (Bucharest). 2019;15(2):182.

6. Khokar AM, Kuchta KM, Moo-Young TA, Winchester DJ, Prinz RA. Increasing trend of bilateral neck exploration in primary hyperparathyroidism. The American Journal of Surgery. 2020;219(3):466-70.

7. Lee NC, Norton JA. Multiple-gland disease in primary hyperparathyroidism: a function of operative approach? Archives of Surgery. 2002;137(8):896-900.

8. Ibraheem K, Toraih EA, Haddad AB, Farag M, Randolph GW, Kandil E. Selective parathyroid venous sampling in primary hyperparathyroidism: 
A systematic review and meta-analysis. The Laryngoscope. 2018;128(11):2662-7.

9. De Feo ML, Colagrande S, Biagini C, Tonarelli A, Bisi G, Vaggelli L, et al. Parathyroid glands: combination of 99mTc MIBI scintigraphy and US for demonstration of parathyroid glands and nodules. Radiology. 2000;214(2):393-402.

10. Bunch PM, Kelly HR. Preoperative imaging techniques in primary hyperparathyroidism: a review. JAMA Otolaryngology-Head \& Neck Surgery. 2018;144(10):929-37.

11. De Maissin C, Leclère J-C, Roudaut N, Thuillier P, Monguillon P, Marianowski R, et al. Evaluation of the performance of ultrasonography and $99 \mathrm{mTc}$-sestamibi scintigraphy for primary hyperparathyroidism surgery. European Annals of Otorhinolaryngology, Head and Neck Diseases. 2020.

12. Yen TW, Wang TS, Doffek KM, Krzywda EA, Wilson SD. Reoperative parathyroidectomy: an algorithm for imaging and monitoring of intraoperative parathyroid hormone levels that results in a successful focused approach. Surgery. 2008;144(4):611-21.

13. Uludağ M. Preoperative Localization Studies in Primary Hyperparathyroidism. Şişli Etfal Hastanesi Tip Bülteni. 2019;53(1):7-15.

14. Jones JJ, Brunaud L, Dowd CF, Duh Q-Y, Morita E, Clark OH. Accuracy of selective venous sampling for intact parathyroid hormone in difficult patients with recurrent or persistent hyperparathyroidism. Surgery. 2002;132(6):94451.

15. Barczynski M, Konturek A, HubalewskaDydejczyk A, Cichon S, Nowak W. Utility of intraoperative bilateral internal jugular venous sampling with rapid parathyroid hormone testing in guiding patients with a negative sestamibi scan for minimally invasive parathyroidectomy-a randomized controlled trial. Langenbeck's archives of surgery. 2009;394(5):827-35.

16. Alvarado R, Meyer-Rochow G, Sywak M, Delbridge L, Sidhu S. Bilateral internal jugular venous sampling for parathyroid hormone determination in patients with nonlocalizing primary hyperparathyroidism. World journal of surgery. 2010;34(6):1299-303.

17. Miller D. Endocrine angiography and venous sampling. Radiologic Clinics of North America. 1993;31(5):1051-67.

18. Edwards CM, Folek J, Dayawansa S, Govednik CM, Quinn CE, Sigmond BR, et al. Central venous parathyroid hormone monitoring using a novel, specific anatomic method accurately predicts cure during minimally invasive parathyroidectomy. The American Journal of Surgery. 2016;212(6):115461.

19. Abdel-Misih SR, Broome JT, Li X, Arrese D, Jacobs JK, Chambers EP, et al. Changing intraoperative parathyroid hormone collection sites from peripheral to central does not affect predictive accuracy during minimally invasive parathyroidectomy. Annals of surgical oncology. 2011;18(3):771-6.

20. Broome JT, Schrager JJ, Bilheimer D, Chambers EP, Jacobs JK, Phay J. Central venous sampling for intraoperative parathyroid hormone monitoring: are peripheral guidelines applicable? The American surgeon. 2007;73(7):712-6.

21. Maceri DR, Kokot N, Green K, Montgomery V, Sharifi J. Split central venous sampling of parathyroid hormone: an adjunct to surgical exploration. Head \& neck. 2011;33(12):1715-8.

22. Liddy S, Worsley D, Torreggiani W, Feeney J. Preoperative imaging in primary hyperparathyroidism: literature review and recommendations. Canadian Association of Radiologists Journal. 2017;68(1):47-55.

23. Gilat H, Cohen M, Feinmesser R, Benzion J, Shvero J, Segal K, et al. Minimally invasive procedure for resection of a parathyroid adenoma: the role of preoperative high-resolution ultrasonography. Journal of Clinical Ultrasound. 2005;33(6):283-7.

24. Kobylecka M, Płazińska MT, Chudziński W, Fronczewska-Wieniawska K, Mączewska J, Bajera A, et al. Porównanie badania ultrasonograficznego i scyntygraficznego w lokalizacyjnej diagnostyce przedoperacyjnej przytarczyc $\mathrm{u}$ chorych $\mathrm{z}$ pierwotną, wtórną i trzeciorzędową nadczynnością-doświadczenia własne.

25. Kluijfhout WP, Vorselaars WM, Vriens MR, Rinkes IHB, Valk GD, de Keizer B. Enabling minimal invasive parathyroidectomy for patients with primary hyperparathyroidism using Tc-99msestamibi SPECT-CT, ultrasound and first results of 18F-fluorocholine PET-CT. European journal of radiology. 2015;84(9):1745-51.

26. Cheung K, Wang TS, Farrokhyar F, Roman SA, Sosa JA. A meta-analysis of preoperative localization techniques for patients with primary hyperparathyroidism. Annals of surgical oncology. 2012;19(2):577-83.

27. Gambaro G, Croppi E, Coe F, Lingeman J, Moe $\mathrm{O}$, Worcester E, et al. Metabolic diagnosis and medical prevention of calcium nephrolithiasis and 
its systemic manifestations: a consensus statement. Journal of nephrology. 2016;29(6):715-34.

28. Vitetta GM, Neri P, Chiecchio A, Carriero A, Cirillo $\mathrm{S}$, Mussetto $\mathrm{AB}$, et al. Role of ultrasonography in the management of patients with primary hyperparathyroidism: retrospective comparison with technetium-99m sestamibi scintigraphy. Journal of ultrasound. 2014;17(1):112.

29. Ruda JM, Hollenbeak CS, Stack Jr BC. A systematic review of the diagnosis and treatment of primary hyperparathyroidism from 1995 to 2003. Otolaryngology-Head and Neck Surgery. 2005;132(3):359-72.

30. Erbil Y, Barbaros U, Yanik BT, Salmaslioğlu A, Tunaci M, Adalet I, et al. Impact of gland morphology and concomitant thyroid nodules on preoperative localization of parathyroid adenomas. Laryngoscope. 2006;116:580-5.

31. Mariani G, Bruselli L, Kuwert T, Kim EE, Flotats A, Israel O, et al. A review on the clinical uses of SPECT/CT. European journal of nuclear medicine and molecular imaging. 2010;37(10):1959-85.

32. Geatti O, Shapiro B, Orsolon PG, Proto G, Guerra UP, Antonucci F, et al. Localization of parathyroid enlargement: experience with technetium-99m methoxyisobutylisonitrile and thallium-201 scintigraphy, ultrasonography and computed tomography. European journal of nuclear medicine. 1994;21(1):17-22.
33. Coakley A, Kettle A, Wells C, O'Doherty M, Collins R. 99Tcm sestamibi-a new agent for parathyroid imaging. Nuclear medicine communications. 1989;10(11):791-4.

34. Greenspan BS, Dillehay G, Intenzo C, Lavely WC, O'Doherty M, Palestro CJ, et al. SNM practice guideline for parathyroid scintigraphy 4.0. Journal of nuclear medicine technology. 2012;40(2):111-8.

35. Eslamy HK, Ziessman HA. Parathyroid scintigraphy in patients with primary hyperparathyroidism: $99 \mathrm{mTc}$ sestamibi SPECT and SPECT/CT. Radiographics. 2008;28(5):146176.

36. Solorzano CC, Carneiro-Pla D. Minimizing cost and maximizing success in the preoperative localization strategy for primary hyperparathyroidism. Surgical Clinics. 2014;94(3):587-605.

37. Ito F, Sippel R, Lederman J, Chen H. The utility of intraoperative bilateral internal jugular venous sampling with rapid parathyroid hormone testing. Annals of surgery. 2007;245(6):959. 